http://jmscr.igmpublication.org/home/

ISSN (e)-2347-176x ISSN (p) 2455-0450

crossref DOI: https://dx.doi.org/10.18535/jmscr/v8i4.18

\title{
Relevance and Role of Hydroxychloroquine in Prophylaxis and Therapy of COVID-19
}

\author{
Authors \\ Dr Arjun Baidya ${ }^{1 *}$, Dr Anand Shankar², Dr Rishad Ahmed ${ }^{3}$, Dr Amit Kumar Das ${ }^{4}$ \\ ${ }^{1}$ Associate Professor, Department of Endocrinology, NRS Medical College \& Hospital, Kolkata, India \\ ${ }^{2}$ Diabetologist, Shankar Diabetes Care Centre, Patna, Bihar \\ ${ }^{3}$ Associate Professor, Department of Medicine, KPC Medical College \& Hospital, Kolkata \\ ${ }^{4}$ Diabetologist, Shree Hospital \& Maternity, Muzaffarpur, Bihar \\ *Corresponding Author \\ Dr Arjun Baidya
}

Associate Professor, Department of Endocrinology, NRS Medical College \& Hospital, Kolkata,

West Bengal, India

\begin{abstract}
A rapidly spreading novel corona virus infection, COVID-19 (Corona virus disease, 2019), a global pandemic has already reported to cause death of approximately $2.5 \%$ of total infected individuals. Being more immunodeficient uncontrolled diabetic individuals have more chance to be symptomatic with COVID-19 than the nondiabetic individuals. There are some recent updates regarding the efficacy of hydroxychloroquine as a monotherapy or with adjunct therapy to improves the condition of COVID-19 infected patients and even the molecule hasthe property to regulate blood glucose level without much hypoglycemia. This review article highlighted the proposed mechanisms of hydroxychloroquine by which it provides beneficial effect in nondiabetic individuals who became symptomatic with COVID-19 as well as being an approved anti diabetic agent how it reduces the chance of infection with COVID-19 in patients with diabetes.
\end{abstract}

Keyword: Hydroxychloroquine, Coronavirus, COVID-19, Diabetes.

\section{Introduction}

Novel Coronavirus COV-2 (COVID-19) pandemic is one of the biggest threats to the mankind and society today. Till the date of writing this article, there are several lakhs of COVID-19 confirmed diagnosed patients worldwide including India and several thousands have died. COVID-19 was first reported in December 2019 in Wuhan City in China. It has since spread across the world and significantly impacted the community health. Till now as there is no specific therapy for COVID-19 prevention of spread of infection is only way to contain this deadly virus. To help stopping the virus spreading everyone should practice good hygiene including washing hands regularly, using a tissue and covering mouth when cough or sneeze and avoiding close contact with others. People are strongly 
encouraged to participate in social distancing behaviors.

Though the evidences are fewer still evidences are pouring in in the scientific literatures regarding the role of chloroquine and its derivative hydroxychloroquine (HCQ) in prophylaxis and therapy of COVID-19 and recommendations has also been evolved. Therefore, in this review we discuss the relevance and role of hydroxychloroquine in prophylaxis and therapy of COVID-19.

\section{COVID-19 and Its Impact}

Coronaviruses are a family of viruses that cause respiratory illnesses. Most of them cause illness in animals, but seven known types of coronaviruses cause illness in humans. Some people even have no symptoms, or only the mild symptoms of common cold ${ }^{[1]}$. SARS-CoV-2 is one of those viruses which causes the illness. SARS-CoV-2 is related to other coronaviruses that cause illness in humans such as those that cause SARS (Severe Acute Respiratory Syndrome) and MERS (Middle East Respiratory Syndrome). Coronaviruses are enveloped positive strand RNA viruses with the largest known RNA genomes, of 30-32 $\mathrm{kb}^{[2]}$.

Based on genome sequencing, corona viruses are divided into three groups (alpha, beta and gamma coronaviruses). Betacoronavirus, murine coronavirus (MuCoV), mouse hepatitis virus (commonly referred to as MHV) are the few types of well-studied coronaviruses. While most coronavirus infections cause the self-limiting common cold in humans, the emergence of the agent for severe acute respiratory syndrome (SARS), the SARS-associated coronavirus (SARS-CoV), also a betacoronavirus, demonstrated the potential for further significant human diseases ${ }^{[3]}$.

The success of coronaviruses in their ability to jump between species may be attributed, in part, to the diverse array of virus entry strategies they deploy to infect target cells ${ }^{[4]}$. Coronavirus entry inside the cells is largely controlled by the spike surface envelope glycoprotein (S) since it bears both receptor binding and membrane fusion capabilities $^{[5]}$. Assuch, the S-glycoproteinis a crucial determinante of tissue and cell tropism as well as host range. Coronaviruses are notable because at each step of virus entry, which includes receptor binding, activation of fusion, and internalization, a multitude of mechanisms and strategies have evolved ${ }^{[6]}$. Coronaviruses can enter cells via fusion either directly at the cell surface or can be internalized through the endosomal compartment. The mouse hepatitis virus (MHV) is a prime example of the flexibility in entry mechanisms used. A variant of the MHV-4strain was shown to be able to fuse directly at the cell surface at neutral $\mathrm{pH}$ and also enter cells through an endocytic route ${ }^{[7]}$. Importantly, coronaviruses employ a diversity of cues, such as receptor binding, low $\mathrm{pH}$ and proteolytic activation, to activate the $S$ protein, allowing a timely release of the fusion peptide into target membranes ${ }^{[4]}$.

COVID-19 is usually a mild disease and around $98 \%$ of people affected survive. The majority of cases $(>80 \%)$ are mild (showing only minimal flulike symptoms) and people can recover at home. Some cases (around 14\%) are severe and very few (around 5\%) can result in critical illness like severe pneumonia with respiratory failure or even death. This is more common in people who have other health problems, particularly the elderly, those with cardiovascular disease, chronic lung disease and hypertension. People with diabetes are among those high-risk categories that can have serious illness if they get the virus.

\section{Diabetes and COVID-19}

Among 72,314 cases, diabetes subjects had 7.3\% higher mortality rates compared to nondiabetic subjects who had $2.3 \%$ mortality as reported by $\mathrm{Wu} \mathrm{Z}$ et $\mathrm{al}^{[6]}$. Xiaobo Yang et al also confirmed that the most distinctive comorbidities of COVID19 were cerebrovascular diseases (22\%) and diabetes (22\%) and documented 32 non-survivors from a group of 52 intensive care unit patients ${ }^{[8]}$. In another study, comorbidities of hypertension $(23.7 \%)$, diabetes mellitus $(16 \cdot 2 \%)$, coronary 
heart diseases $(5 \cdot 8 \%)$, and cerebrovascular disease (2.3\%) documented in 1099 patients with confirmed COVID-19 ${ }^{[9]}$.

\section{Relevance of Hydroxychloroquine in COVID- 19}

Hydroxychloroquine will as a prophylactic drug and is acting as a therapeutic agent against COVID-19 infection and it is a game changer in fight against the COVID-19.

Hydroxychloroquine acts on host target respiratory cells by increasing the endosomal $\mathrm{pH}$ required for the virus- host target cell fusion. Firstly, increase in the $\mathrm{pH}$ disrupts the normal viral function. Secondly, in SARS-coronavirus, which is a sister to COVID-19, hydroxychloroquine was found to interfere with the glycosylation of cellular receptors of the virus. This interference eventually resulted in no association between the host target cell and the virus (Figure 1). This interference eventually resulted in no association between the host target cell and the virus (Figure 1). Thirdly, hydroxychloroquine acts as an ionophoric agent for Zinc ions and thus increases the influx of Zinc ions into the cytoplasm of host target cells regardless whether the host target cells are infected or not ${ }^{[10]}$. Zinc ions adhere to the RNA dependent RNA polymerase enzyme of the virus and stops COVID-19 polymerization intracellularly.

All the above-mentioned mechanism is on the host cells and COVID-19 can't mutate and cause resistance to these three mechanisms. First two mechanisms inhibit the virus-target host cell union. ACE-2 (Angiotensin converting enzyme-2) is a surface receptor found on target host cell.
Hydroxychloroquine results in disablement of ACE2 terminal glycosylation which leads to the morphological change. This results in the disruption in the association between the COVID19 and target host cell as COVID-19 requires ACE-2 receptor to attach to a cell ${ }^{[11]}$.

Because the action is on the target host cell, hydroxychloroquine won't develop resistance therapeutically. If a person not yet exposed to the COVID-19 infection and subsequently after taking hydroxychloroquine some viruses enters inside the body and try to infect target host cells, hydroxychloroquine first and second mechanism will prevent the union of virus-target host cell. If some of the viruses enters the target host cell, Zinc ions present inside the cells adhere to the RNA dependent RNA polymerase enzyme of the virus and stops COVID-19 polymerization intracellularly. If COVID-19 mutates inside the cell several times, even then the Zinc ions would actively inhibit the viral multiplication inside the host respiratory cells, irrespective of the viral strain. Even if COVID-19 virus manages to escape from Zinc ions trap and releases from the host target cell cytoplasm into the interstitial matrix, intercellular space, and tried to re-infect some of the healthy target host cells, Hydroxychloroquine will prevent the re-union of viral genome with target host cells via the first two mechanisms and the infection will halt in the preliminary stages itself and complications like COVID-19 pneumonia will not develop. Hydroxychloroquine molecules will not lose it's effectively in an individual pre and post infection. 


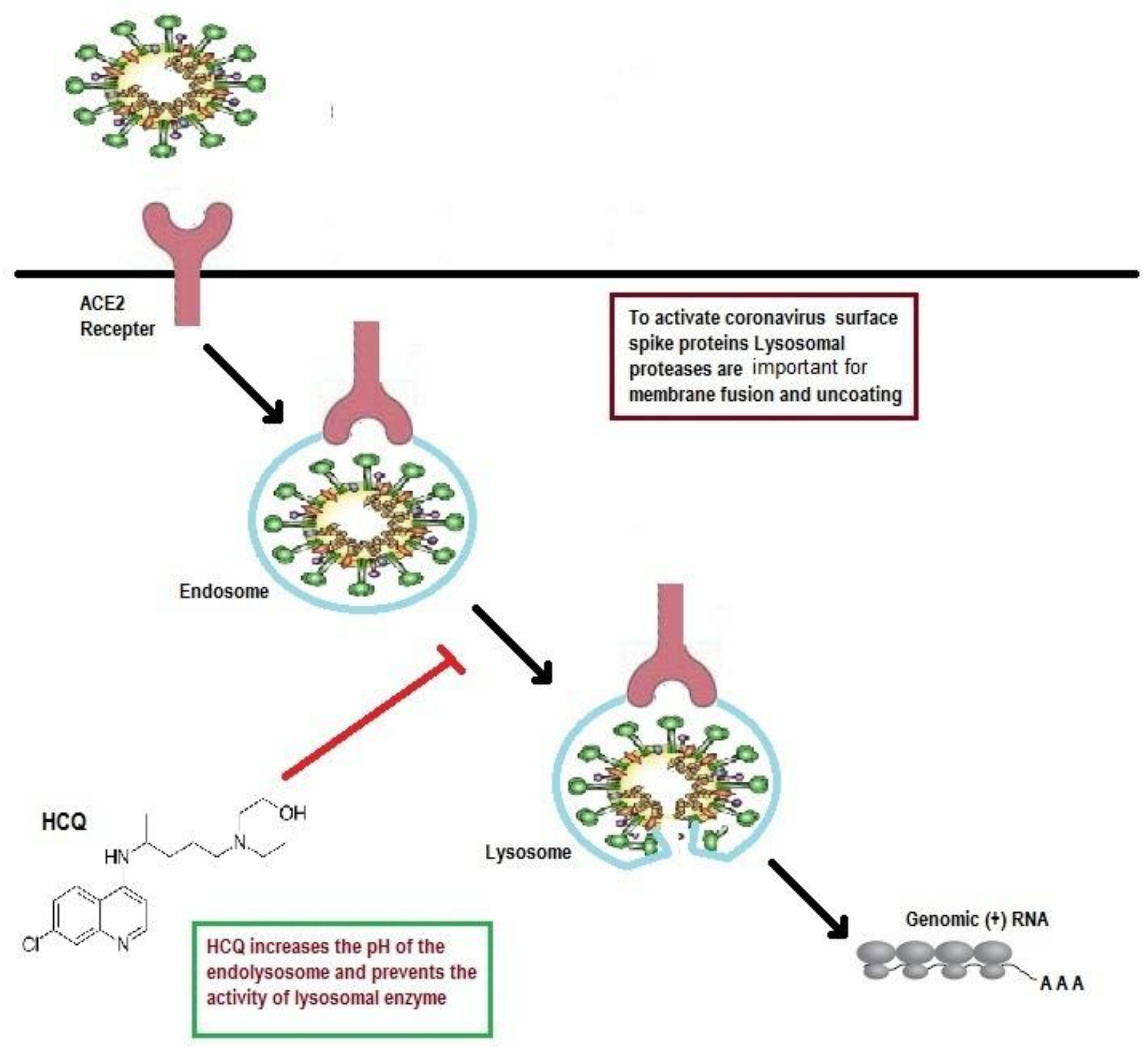

Figure 1: The mechanisms of action of hydroxychloroquine (HCQ) against COVID-19

Lysosomal $\mathrm{pH}$ elevation with hydroxychloroquine was reported from about 4.5 to 6.5 at $100 \mu \mathrm{M}^{[12]}$. It was reported that safe dosage i.e. 6 to $6.5 \mathrm{mg} / \mathrm{kg}$ per day of hydroxychloroquine could generate serum level of $1.4-1.5 \mu \mathrm{M}$ in human ${ }^{[13]}$. A recent study in line with this, also confirm that safe dosage of hydroxychloroquine concentration in the above tissues is likely to be achieved to inhibit COVID-19 infection ${ }^{[14]}$. This trial also concludes that, hydroxychloroquine not only attenuate the inflammatory response but also decrease the level of cytokines which generally higher in patients infected with SARS-CoV-2. One study found that hydroxychloroquine is more potent than chloroquine in inhibiting SARS-CoV-2 ${ }^{[15]}$.

A recent study shows that hydroxychloroquine treatment is significantly associated with viral load reduction/disappearance in COVID-19 patients and its effect is reinforced by azithromycin $^{[16]}$. 
The precise mechanism by which hydroxychloroquine improves glycemic control has not been certainly elucidated. The drug is purported to act by increasing the metabolic effect of insulin by reducing its lysosomal degradation. The drug has been demonstrated to inhibit the production of inflammatory markers such as TNF$\boldsymbol{\alpha}$, IL-1, IL 6 and interferon- $\boldsymbol{\gamma}$ which are linked to the development of insulin resistance ${ }^{[17]}$. Animal studies have demonstrated that administration of hydroxychloroquine has contributed to the lowering of IL-1 $\boldsymbol{\beta}$, IL-6 and TNF- $\boldsymbol{\alpha}$ and transforming growth factor $\boldsymbol{\beta} 1$, which in turn resulted in the preservation of islets of Langerhans structure $^{[18]}$. Mercer et al. Have demonstrated that 6 weeks of hydroxychloroquine therapy has contributed to significant increase in insulin sensitivity from 4.5 to 8.9 in obese non-diabetic subjects $^{[19]}$.

In India current recommendation is to use hydroxychloroquine in combination with sulphonylurea and metformin. The 2018 Research Society for the Study of Diabetes in India (RSSDI) guidelines have placed hydroxychloroquine as third line of drug indicated for the management of $\mathrm{T} 2 \mathrm{DM}^{[20]}$.

\section{Role of Hydroxychloroquine in COVID-19 In treatment}

So far till date $\left(25^{\text {th }}\right.$ March, 2020) no authority has issued confirmed dosing recommendations for Hydroxychloroquine for the treatment of COVID19 infection. Therefore, the dosing regimen of Hydroxychloroquine reported in the recently published articles have been discussed below.

In French Study of Hydroxychloroquine and Azithromycin as a treatment of COVID- 19 $(\mathrm{N}=20$ hydroxychloroquine-treated patients and 16 control patients), Hydroxychloroquine sulfate $200 \mathrm{mg}$, three times per day for ten days was the dosing regimen used. Among hydroxychloroquine-treated patients six patients received Azithromycin (500mg on day1 followed by $250 \mathrm{mg}$ per day, the next four days) to prevent

\section{bacterial}

super-infection

under

daily electrocardiogram control ${ }^{[16]}$.

Regimen based on simulated lung concentration based on in-vitro study Yao X et al recommended hydroxychloroquine 400mg BID at day 1 and 200mg BID Day-2 to Day- $5^{[15]}$.

For infants and childrenIranian Expert's Consensus Statement recommend hydroxychloroquine sulfate, i.v.,3 - $5 \mathrm{mg} / \mathrm{kg} /$ day (max dose $400 \mathrm{mg}$ ), BID for 5 days ${ }^{[21]}$.

Recommendations for COVID-19 clinical management Rome, Italy recommended Clinical management based on case severity and for following categories of patients Hydroxychloroquine has been recommended

- Asymptomatic or mild infection

- Patient affected by respiratory symptoms, clinically unstable, not in critical conditions (e.g.: MEWS clinical deterioration score 3-4)

- Critical patient (e.g. MEWS clinical deterioration score $>4)^{[22]}$

Hydroxychloroquine phosphate recommended dosage for above categories is $400 \mathrm{mg}$ tablet, 1 tabletas loading dose, followed by $200 \mathrm{mg}$ tablet, 1 tablet q12hour, for 10 days. They have also recommended that before chloroquine and hydroxychloroquine administration, G6PD deficiency test should be performed ${ }^{[22]}$.

\section{In prophylaxis}

Asymptomatic healthcare workers involved in care of suspected or confirmed cases of COVID19: $400 \mathrm{mg}$ twice a day on day 1 , followed by $400 \mathrm{mg}$ once weekly for next 7 weeks; to be taken with meals. Asymptomatic household contacts of laboratory confirmed cases: $400 \mathrm{mg}$ twice a day on day 1 , followed by $400 \mathrm{mg}$ once weekly for next 7 weeks; to be taken with meals ${ }^{[23]}$.

Interim clinical guidelines for supportive care \& antiviral treatment of hospitalized patients with suspected or confirmed COVID-19 in Belgium are given in the table below ${ }^{[24]}$. 
Table: Interim guidelines for supportive care \& antiviral treatment of hospitalized patients with suspected or confirmed COVID-19 ${ }^{[24]}$.

\begin{tabular}{|c|c|c|c|}
\hline Clinical category & $\begin{array}{l}\text { Supportive } \\
\text { Care }\end{array}$ & Additional antiviral therapy & Precautions \\
\hline $\begin{array}{l}\text { Confirmed COVID-19 } \\
\text { - Mild-to moderate disease } \\
\text { (no O2 requirement/no } \\
\text { evidence of pneumonia) } \\
\text { - Risk group } \#^{1} \\
\\
\left({ }^{\# 1} \text { Risk groups: age > } 65 \text { years }\right. \\
\text { AND/OR underlying end } \\
\text { organ dysfunction (lung, } \\
\text { heart, liver,...), diabetes, } \\
\text { coronaropathy, obstructive } \\
\text { chronic ary disease, arterial } \\
\text { pulmonary } \\
\text { hypertension ) }\end{array}$ & $\begin{array}{l}\text { Symptomatic } \\
\text { treatment }\end{array}$ & $\begin{array}{l}\text { Consider to start hydroxychloroquine } \\
\text { if no contra-indication } \\
\quad 400 \mathrm{mg} \text { at suspicion/diagnosis; } \\
\quad 400 \mathrm{mg} 12 \mathrm{~h} \text { later } \\
\text { •Followed by } 200 \mathrm{mg} \text { BID up to } \\
\text { Day } 5 \\
\text { NB: } \\
\text { stop hydroxychloroquine if follow-up at } \\
\text { home } \\
\text { If no hydroxychloroquine available, } \\
\text { consider chloroquine base } 600 \mathrm{mg} \\
(10 \mathrm{mg} / \mathrm{kg}) \text { at diagnosis and } 300 \mathrm{mg}(5 \\
\mathrm{mg} / \mathrm{kg}) 12 \mathrm{~h} \text { later, followed by } 300 \mathrm{mg} \\
(5 \mathrm{mg} / \mathrm{kg}) \text { BID up to Day } 5 \text { or } \\
\text { chloroquine phosphate } 1000 \mathrm{mg} \text { at } \\
\text { diagnosis and 500mg } 12 \mathrm{~h} \mathrm{later,} \\
\text { followed by 300mg BID up to day } 5\end{array}$ & $\begin{array}{l}\text { Contra-indications } \\
\text { - QTc }>500 \text { msec } \\
\text { - Check for drug interaction } \\
\text { - Interaction potential of } \\
\text { hydroxychloroquine is likely the } \\
\text { same as chloroquine } \\
\text { - Myasthenia gravis } \\
\text { - Porphyria } \\
\text { - Retinal pathology } \\
\text { - Epilepsy } \\
\text { NB: pregnancy is not a contra- } \\
\text { indication as such (large safety } \\
\text { experience with chloroquine); see } \\
\text { risk/benefit balance } \\
\text { Perform ECG daily if initial QTc } \\
450-500 \text { msec, and biochemistry } \\
\text { according to underlying disease }\end{array}$ \\
\hline $\begin{array}{l}\text { Confirmed COVID-19 } \\
\text { Severe disease } \\
\text { - } \geq 1 \text { of the following: } \\
\text { - Respiratory rate } \geq 30 / \text { min } \\
\text { (adults); } \geq 40 / \text { min (children } \\
<5 \text { ) } \\
\text { - Blood oxygen saturation } \\
\leq 93 \% \\
\text { - } \mathrm{PaO} 2 / \mathrm{FiO} 2 \text { ratio }<300 \\
\text { - Lung infiltrates }>50 \% \text { of } \\
\text { the lung field within } 24-48 \\
\text { hours }\end{array}$ & $\begin{array}{l}\text { Optimal } \\
\text { supportive } \\
\text { care in } \\
\text { hospital } \\
\text { WARD (or } \\
\text { ICU) } \\
\text { Provide } 02 \\
\text { Consider } \\
\text { carefully } \\
\text { antibiotics or } \\
\text { antifungals } \\
\text { according to } \\
\text { local } \\
\text { epidemiology }\end{array}$ & $\begin{array}{l}\text { Start hydroxychloroquine } \\
\text { if no contra-indication } \\
\text { • } 400 \mathrm{mg} \text { at diagnosis; } \\
\text { • } 400 \mathrm{mg} 12 \mathrm{~h} \text { later } \\
\text { • Followed by } 200 \mathrm{mg} \text { BID up to Day } 5 \\
\mathrm{NB} \text { If no hydroxychloroquine } \\
\text { available, consider chloroquine base } \\
600 \mathrm{mg}(10 \mathrm{mg} / \mathrm{kg}) \text { at diagnosis and } \\
300 \mathrm{mg}(5 \mathrm{mg} / \mathrm{kg}) 12 \mathrm{~h} \text { later, followed } \\
\text { by } 300 \mathrm{mg}(5 \mathrm{mg} / \mathrm{kg}) \text { BID up to Day } 5 \\
\text { OR chloroquine phosphate } 1000 \mathrm{mg} \text { at } \\
\text { diagnosis and } 500 \mathrm{mg} \quad 12 \mathrm{~h} \text { later, } \\
\text { followed by } 300 \mathrm{mg} \text { BID up to day } 5 \\
\text { Consider lopinavir/ritonavir } 400 / 100 \\
\text { mg (= } 2 \text { tablets of } 200 / 50 \mathrm{mg}) \text { BID for } \\
14 \text { days) } \\
\text { as second choice ONLY if } \\
\text { hydroxychloroquine/chloroquine } \\
\text { contra-indicated and provided it can } \\
\text { be administered within 10 days after } \\
\text { symptoms onset (check also drug } \\
\text { interaction!); or in children < } 10 \mathrm{~kg} \\
\text { (after IDS advice) }\end{array}$ & $\begin{array}{l}\text { Contra-indications } \\
\text { - QTc > } 500 \text { msec } \\
\text { - Check for drug interaction } \\
\text { - Interaction potential of } \\
\text { hydroxychloroquine is likely the } \\
\text { same as chloroquine } \\
\text { - Myasthenia gravis } \\
\text { - Porphyria } \\
\text { - Retinal pathology } \\
\text { - Epilepsy } \\
\text { NB: pregnancy is not a contra- } \\
\text { indication as such (large safety } \\
\text { experience with chloroquine); see } \\
\text { risk/benefit balance } \\
\text { Perform ECG daily if initial QTc } \\
450-500 \text { msec, and biochemistry } \\
\text { according to underlying disease } \\
\text { Perform basic biochemistry daily } \\
\text { and ECG daily if initial QTc }>450 \\
\text { msec (+ other indicated } \\
\text { investigations) } \\
\text { Avoid quinolones if possible, or } \\
\text { monitor closely the QT if these } \\
\text { antibiotics are needed } \\
\text { In case antibiotics must be } \\
\text { provided, consider to add } \\
\text { azithromycin (given its possible } \\
\text { synergistic effect } \\
\text { hydroxychloroquine) BUT with a } \\
\text { particular caution for interaction } \\
\text { and QTc prolongation (daily ECG } \\
\text { or cardiac monitoring) }\end{array}$ \\
\hline
\end{tabular}




\section{Conclusion}

There are only few small trialswhich confirmed the beneficial effects of hydroxychloroquine to treat recent COVID-19 global pandemic. For prevention of COVID-19 hydroxychloroquine is the drug choice as of now. As hydroxychloroquine has already been shown antidiabetic effect and approved in India for uncontrolled T2DM, adding this molecule in uncontrolled T2DM might provide dual benefit in the current scenario of COVID-19 pandemic. But before large scale use larger randomized controlled trial is warranted.

\section{Disclosure}

The authors report no conflicts of interest in this work.

\section{Reference}

1. www.idf.org/our-network/regionsmembers/europe/europe-news/196information-on-corona-virus-disease2019-covid-19-outbreak-and-guidance-forpeople-with-diabetes.html

2. Almazan, F., Gonzalez, J. M., Penzes, Z., Izeta, A., Calvo, E., Plana-Duran, J., et al. (2000). Engineering the largest RNA virus genome as an infectious bacterial artificialchromosome. Proc. Natl. Acad. Sci. USA97:5516-5521

3. An, S., Chen, C. J., Yu, X., Leibowitz, J. L., and Makino, S. (1999). Induction of apoptosis inmurine coronavirus-infected cultured cells and demonstration of $E$ protein as an apoptosis inducer. $\mathrm{J}$. Virol.73:7853-7859.

4. B.J. Bosch and P. Rottier Perlman, Gallagher, Snijder (Eds.), Mechanisms of coronavirus cell entry mediated by the viral spike protein Nidoviruses, ASM Press, Washington, D.C. (2008), pp. 157178

5. S. Belouzard, J.K. Millet, B.N. Licitra and G.R. Whittaker Mechanisms of coronavirus cell entry mediated by the viral spike protein Viruses, 4 (6) (2012), pp. 1011-1033

6. Wu Z, McGoogan JM, Characteristics of and important lessons from the corona virus disease 2019 (COVID-19) outbreak in chains: summary of report of 72312 cases from the Chinese centre for disease control and prevention. J Am Med Assoc 2020 Feb 24

7. T.C. Nash and M.J. Buchmeier. Entry of mouse hepatitis virus into cells by endosomal and nonendosomal pathways. Virology, 233 (1) (1997), pp. 1-8.

8. Yang $\mathrm{X} \mathrm{Yu} \mathrm{Y} \mathrm{Xu} \mathrm{J} \mathrm{et} \mathrm{al.} \mathrm{Clinical} \mathrm{course}$ and outcomes of critically ill patients with SARS-CoV-2 pneumonia in Wuhan, China: a single-centered, retrospective, observational study. Lancet Respir Med. 2020.

9. Guan W Ni Z Hu Y et al. Clinical characteristics of coronavirus disease 2019 in China. N Engl J Med. 2020.

10. Zhou N, Pan T, Zhang J, Li Q, Zhang X, Bai C, et al. Glycopeptide antibiotics potently inhibit cathepsin $\mathrm{L}$ in the late endosome/lysosome and block the entry of Ebola virus, middle east respiratory syndrome coronavirus (MERS-CoV), and severe acute respiratory syndrome coronavirus (SARS-CoV). J Biol Chem 2016;291:9218e32.

11. Lai CC, Liu YH, Wang CY, Wang YH, Hsueh SC, Yen MY, et al. Drug treatment options for the 2019- new coronavirus (2019-nCoV). Biosci Trends 2020 Jan 28.

12. Ohkuma S. \& Poole B. Fluorescence probe measurement of the intralysomsomal $\mathrm{pH}$ in living cells and the perturbation of $\mathrm{pH}$ by various agents. Proc. Natl Acad. Sci. USA 75, 3327-3331 (1978).

13. Laaksonen A. L Koskiahde V \&Juva K. Dosage od antimalarial drugs for children with juvenile rheumatoid arthritis and systemic lupus erythematous. A clinical study with determination of serum 
concentrations of chloroquine and hydroxychloroquine. Scand. J. Rheumatol. 3, 103-108.

14. Jia Liu, Ruiyan Cao, Mingyue Xu, Xi Wang, Huanyu Zhang, Hengrui $\mathrm{Hu}$, Yufeng Li, Zhihong $\mathrm{Hu}$, Wu Zhong and Manil Wang. Hydroxychloroquine, a less toxic derivative of chloroquine, is effective in inhibiting SARS-CoV-2 infection in vitro. Cell Discovery (2020)6:16.

15. Yao X, Ye F, Zhang M, Cui C, Huang B, Niu $P$, et al. In vitro Antiviral activity and projection of optimised dosing Design of Hydroxychloroquine for the treatment of Severe Acute Respiratory Syndrome Coronavirus 2 (SARS-CoV-2). Clin Infect Dis. 2020 Mar 9. Pii: ciaa237.

16. Gautret et al. (2020) Hydroxychloroquine and azithromycin as a treatment of COVID- 19: results of an open- label non- randomized clinical trial. International Journal of Antimicrobial Agents - In Press 17 March 2020.

17. Toledo F. Mechanisms of Action of Hydroxychloroquine in reducing risk of Type 2 Diabetes. Grantome [Internet]. [cited 2018 Jul 20]; available from http://grantome.com/grant/NIH/R21DK082878-02.

18. Solomon DH, Garg R, LuB, Todd DJ, Mercer E, Norton $\mathrm{T}$, et al. Effect of hydroxychloroquine on insulin sensitivity and lipid parameters in rheumatoid arthritis patients without diabetes mellitus: a randomized, blinded crossover trial. Arthritis Care Res (Hoboken). 2014 Aug;66(8):1246-51.

19. Mercer E, Rekedal L, Gang R, Lu B, Massarotti EM, Solomon DH. Hydroxychloroquine improves insulin sensitivity in obese non-diabetic individuals. Arthritis Res There. 2012;14(3):R135.
20. Bajaj S. RSSDI clinical practice recommendation for the management of type 2 diabetes mellitus 2017. Int $\mathbf{J}$ Diabetes Dev Ctries. 2018 Mar; 38 (Suppl1):1-115.

21. Abdollah Karimi et al. Treatment of COVID-19 in Children: Iranian Expert's Consensus Statement. Arch Pediatr Infect Dis. 2020 April; 8(2):e102400.

22. National Institute for the Infectious Diseases "L. Spallanzani", IRCCS. Recommendations for COVID-19 clinical management Rome, Italy. Infectious Disease Reports 2020; 12:8543

23. National Task force on COVID-19 constituted by Indian Council of Medical Research recommendations for use of hydroxychloroquine for prophylaxis of SARS-CoV-2 infection for selected individuals issued on $22^{\text {nd }}$ March 2020.

24. https://epidemio.wivisp.be/ID/Documents/Covid19/COVID19_InterimGuidelines_Treatment_ENG.pd f. 